\title{
Development of powtoon animation learning media in improving understanding of mathematical concept
}

Rizkiana Akmalia, Fajriana*, Rohantizani, Hayatun Nufus, \& Wulandari

Department of Mathematics Education, Universitas Malikussaleh, Aceh Utara, Indonesia

*Corresponding author: fajriana@unimal.ac.id | Phone Number: +628126344994

\section{ARTICLE INFO}

Received: 26-07-2021

Received in revised: 24-08-2021

Accepted: 19-09-2021

Available online: $30-10-2021$

\section{KEYWORDS}

Animation Powtoon;

Development of media;

Mathematical concepts;

\section{A B S T R A C T}

The purpose of this development research is to determine the feasibility and effectiveness of using Powtoon animation learning media for flat-sided geometry. The development model used is the ADDIE model. The subjects of this study were students of class VIII-2 MTsS Syamsuddhuha (junior high religious school). The percentage results of product assessment by media experts are $96 \%$ in the very feasible category, the percentage result of product assessment by material experts is $92 \%$ in the very feasible category, and the percentage result of product assessment by 10 small group students is $94 \%$ in the very feasible category. Based on the results of the product assessment by all validators who stated that it was very feasible, the Powtoon animation learning media developed had meet the criteria for use for students. The effectiveness of using the product can be seen from the results of the comparison of the students' average pretest and posttest scores. The resulting product is effective in increasing the understanding of mathematical concepts, as evidenced by the average pretest score of 43,44 , an increase in the posttest of 84,27 , and the $\mathrm{N}$-Gain value of 0,72 in the high category. It can be concluded that Powtoon animation learning media is feasible and effective to be used in improving the understanding of mathematical concepts.

\section{INTRODUCTION}

Along with the times, science and technology have also developed. The development of science and technology from day to day is becoming more sophisticated, directly or indirectly, has a considerable influence on aspects of education (Adhkar, 2016:1). According to Pratiwi (2017: 951), Education is an effort to provide certain skills to humans and develop their talents and personalities to be able to deal with any changes that occur. Due to the advancement of science and technology, humans try to develop themselves through education. Therefore, the implementation of education requires careful planning and implementation so that the expected progress of a nation is achieved optimally. The progress of a nation is determined by the level of knowledge developed in the lives of citizens. One of the knowledge possessed by humans is in the form of scientific knowledge or commonly referred to as science. Mathematics is one of the sciences that must be studied because it can be applied and can help everyday people (Nurhairunnisah, 2017:3).
The development of information and communication technology today is inseparable from the existence of mathematics. Until now, mathematics is still considered a difficult, boring, and scary subject. The existence of this assumption is due to the lack of students' understanding of the material in mathematics. This assumption may not be an exaggeration, in addition to having an abstract nature, mathematics also requires a good understanding of concepts, because understanding new concepts requires a prerequisite for understanding previous concepts. Learning mathematics has a relationship with understanding the concepts being studied. Mathematical concepts are interrelated with each other so that to learn it must be coherent and continuous. If students have understood mathematical concepts, it will make it easier for students to learn the next more complex mathematical concepts (Sumaryati, 2017:991). Understanding learning concepts is the first step to making it easier for students to learn. Therefore, the ability to understand concepts is very 
important for students to have as a basis for understanding subsequent concepts and solving various mathematical problems.

Many of basic competencies in Permendikbud (Minister of Education Regulation) number 24 of 2016 emphasize the importance of students' understanding of learning materials. However, at this time, the low ability to understand mathematical concepts is one of the problems faced in education, especially education in Indonesia. The low understanding of students' concepts is caused by the low quality of the learning process. This can be seen from the results of the 2015 TIMSS (Trend in Mathematics and Science Study) published in December 2016 (Kartika, 2018:778) which shows that the achievement of Indonesian students in mathematics is ranked 46 out of 51 countries with a score of 397. the activeness of students to develop and find concepts is still very low. This is also evidenced by the results of observations made by researchers at MTsS Syamsuddhuha (junior high religious school) by providing several questions related to students' understanding of concepts. The researcher found that there were still many students who were less able to answer the questions given. One of the questions asked was as follows:

The escalator ladder maker will build the ladder with a floor length of 12 meters and a height of 5 meters. From the problems above:

a. Make a sketch of the picture of the problem according to what is known in the problem and determine the solution formula!

b. Determine how long the ideal ladder should be built by the craftsman!

c. The following is the answer of one of the students who was given the question:

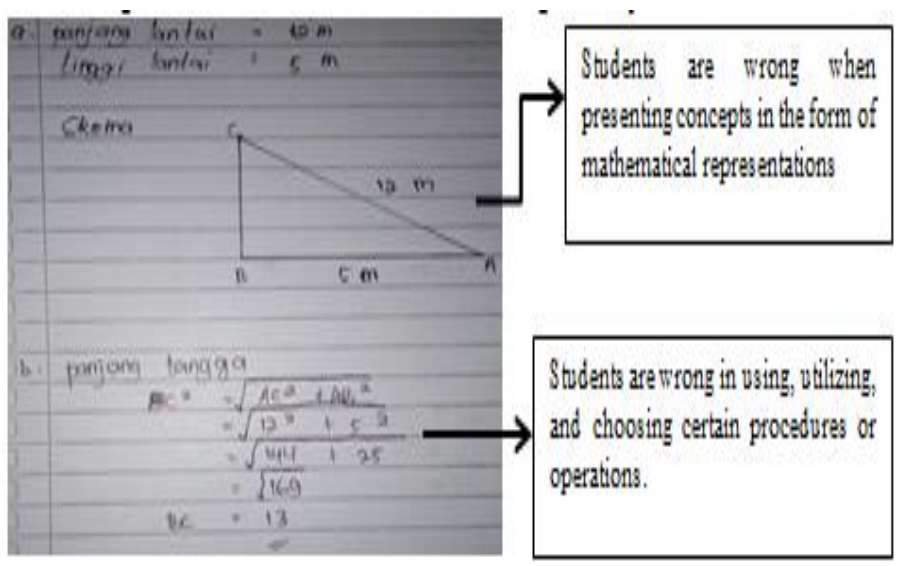

Figure 1. Example of student answers

Based on the answers given by students in Figure 1 above, it can be seen that students are less precise in presenting concepts in the form of mathematical representations and students cannot choose the right procedure or operation to solve the problem. In accordance with these answers, researchers can find out that the ability to understand students' mathematical concepts is still low.
The low understanding of students' concepts can also be caused by the lack of use of interesting and varied learning media. This is also evidenced by the results of the documentation of the learning media that the researchers photographed when the teacher carried out the learning process in the classroom. The following are the results of the documentation of the use of learning media in the classroom.

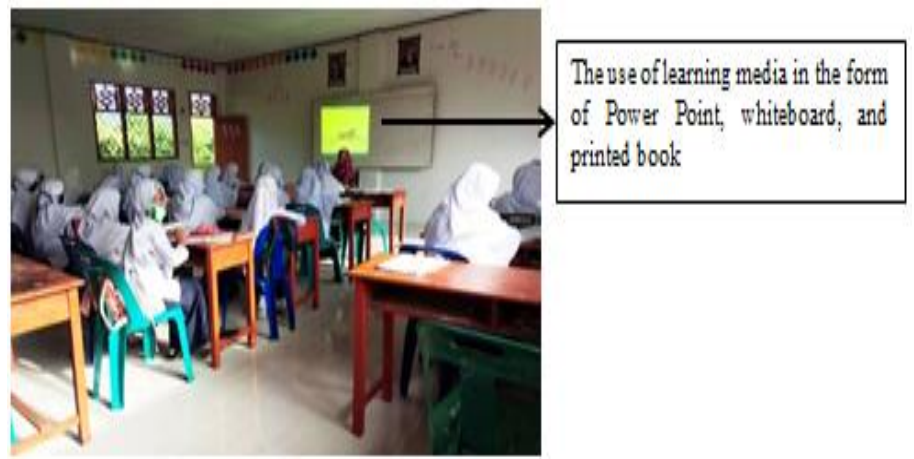

Figure 2. Example of using learning media

The results of the documentation above are clarified by the results of interviews at the observation stage conducted by researchers with one of the mathematics teachers at MTsS Syamsuddhuha (junior high religious school) who said that the learning media used were still in the form of blackboards, printed books, occasionally using Power Point and several learning videos downloaded via YouTube. However, there is no learning media in the form of videos made by the teacher. This happens due to the limited time of teachers who do not have time to prepare new learning media and the lack of understanding of teachers regarding the use of today's technology learning media. According to him, it is difficult to apply technology media because the manufacturing method is quite complicated and takes a long time, especially when the ability to technology is still lacking. Whereas the use of varied learning media in the classroom is an innovation in technology which is also very influential in improving students' learning abilities, especially students' mathematical concept understanding abilities.

The use of learning media can help students to understand the material more quickly and understand concepts. According to Kustandi (2011: 9) learning media is a tool that can help the teaching and learning process and serves to clarify the meaning of the message conveyed so that it can achieve learning objectives properly and perfectly. Learning media can be grouped into four groups, namely media resulting from print technology, media resulting from audio-visual technology, media resulting from computer-based technology, and media resulting from a combination of print and computer technology.

Therefore, interesting and varied learning media are needed by students as a tool to clarify the understanding of the concepts conveyed by the teacher. Starting from the 
potential and problems faced by teachers, students, and the results of initial observations in schools, it is necessary to develop a new interactive learning media that is easy to manufacture, inexpensive, and requires little time but the results are effective and efficient in learning. One of them is the Powtoon application that can be used as a learning medium, where the way of making it is like Power Point but the results are in the form of videos like made with flash which are more lively, interesting, and not boring.

Powtoon is an Audio Visual-based media in the form of an online service that can be accessed directly via Google to create a presentation video that has interesting animation features and an easy-to-understand timeline. The animation features in question include handwriting, animated cartoons, and livelier transition effects (Latifah \& Lazulfa, 2020:27). The use of this livelier animation will make students more focused on the presentation given. Powtoon animation media emphasizes that students know and understand the real form of learning. With the Powtoon animation media, it will affect the level of understanding of students' mathematical concepts in the teaching and learning process because the form of the material is presented with various animations and can also use sound recordings as a support to clarify the material presented.

The development of Powtoon animation learning media is based on previous research conducted by Awalia et al (2019) which stated that Powtoon animation learning media can help students understand the concepts of mathematics subjects on the circumference and area of flat shapes. Furthermore, based on Jatiningtias (2017) it also states that by using Powtoon learning media there are significant differences in learning outcomes. This is in line with research by Ariyanto et al., (2018) which states that the use of Powtoon media can increase student interest and learning outcomes. This development is also based on Maesyarah (2018) which states that learning videos made with Powtoon are categorized as very feasible and interesting to use based on the validation of media experts, material experts, teacher assessments and student responses. This research by Maesyarah is further strengthened by the research conducted by Aprilianti (2019) which states that the mathematics learning media using Powtoon has met the valid/feasible criteria for use for students. Based on the results of the several studies above, it can be concluded that one way to improve students' understanding of mathematical concepts is to develop valid/feasible mathematics learning media so that researchers intend to develop learning media using the Powtoon application.

Based on the explanation of the problems above, the researcher feels that learning media using Powtoon animation can help clarify the mathematical concepts presented. So, the researchers are interested in conducting research with the title "Development of powtoon animation learning media in improving understanding of mathematical concept". Based on the background of the problem above, the problems that will be studied are: 1) How is the feasibility of developing Powtoon animation learning media in improving students' understanding of mathematical concepts in the material for building flat sides of cubes and blocks for class VIII MTsS Syamsuddhuha?; and 2) How effective is the use of Powtoon animation learning media in improving students' understanding of mathematical concepts in the material for building flat sides of cubes and blocks for class VIII MTsS Syamsuddhuha?

The objectives of this development are: 1) To determine the feasibility of developing Powtoon animation learning media in improving students' understanding of mathematical concepts in the material for building flat sides of cubes and blocks for class VIII MTsS Syamsuddhuha; and 2) To determine the effectiveness of using Powtoon animation learning media in improving students' understanding of mathematical concepts in the material for building flat sides of cubes and blocks for class VIII MTsS Syamsuddhuha.

\section{LITERATURE REVIEW}

\section{Learning media development}

According to Mulyaningtias (2016:18) development is a process used to develop and validate a product. Development can be in the form of process, product, and design. Development is research, usually used in education called development research. Research and development or in English Research and Development is research that is used to produce certain products and test the effectiveness of certain products (Sugiyono, 2018:297). The purpose of this research is to produce new products in the form of learning media in education through development. Based on the definition of development described above, the researcher concludes that development is a research process used to develop, produce, validate, and test the effectiveness of certain products with the aim of obtaining appropriate and effective product results for use.

According to Gerlach and Ely (in Arsyad, 2013:3) states that the media if understood in broad outline are humans, materials or events that build conditions that make students able to acquire knowledge, skills or attitudes. According to Sukiman (2012:29) learning media are everything that can be used to channel messages from the sender to the recipient so that it can stimulate the thoughts, feelings, concerns, and interests of students in such a way that the learning process occurs in order to achieve learning objectives effectively. Furthermore, according to Jatiningtias (2017:26) learning media are all tools used in the learning process, with the intention of conveying learning messages (information) from sources or teachers 
to recipients in this case students and enabling communication between teachers and students to take place. well. Based on the opinions of Sukiman \& Jatiningtias, it can be concluded that learning media is a tool or vehicle for distributing messages or learning information that can be used to convey information or messages from teachers to students so that they can stimulate students' thoughts, feelings, attention, and interest in the learning process. learning in order to achieve learning objectives effectively.

\section{Characteristics of learning media}

Arsyad (2013:15-17) suggests three characteristics of media which are an indication of why the media is used and what media can do that the teacher may not be able (or less efficient) to do. The three characteristics are: 1) Fixative property: This characteristic describes the ability to record, store, preserve, and reconstruct an event or object, 2) Manipulative property: Transformation of an event or object is possible because the media has characteristics. manipulative. Events that take time every day can be presented to students in two or three minutes with the technique of time-lapse recording. For example, the process of larvae becoming a cocoon and then becoming a butterfly can be accelerated with the photographic recording technique, and 3) Distributive property: The distributive property of the media allows an object or event to be transformed through space, and simultaneously the event is presented to a large number of people. students with a relatively similar experience stimulus with the incident.

\section{Functions and benefits of learning media}

Media functions for instructional purposes where the information contained in the media must involve students both in mind or mentality as well as in the form of real activities so that learning can occur (Sukiman, 2012:38). Learning media can help students improve understanding, present data in an attractive and reliable way, facilitate data interpretation and condense information. The use of learning media at the teaching orientation stage will greatly help the effectiveness of the learning process and the delivery of messages and learning content at that time (Jatiningtias, 2017:27).

The benefits of using learning media according to Ramli (2012:7) are: 1) Provide feedback for the improvement of learning that has taken place or will be planned, 2) The subject matter for learners is more functional and feels useful for them, 3) Provides enrichment experience (enrichment) directly to students on what has been conveyed by the learner, 4) Familiarize students to be more convincing about the learning being taught, so that it will lead to respect and admiration for the learner, 5) The feeling of the learner will feel deep in him by meeting the concepts being taught students with what they get outside of school, and 6) Indirectly students get used to conducting comparative studies of the material provided by the teacher with what they get from learning media in the school area. Meanwhile, Sudjana \& Rivai (2011:2) suggest the benefits of learning media in the student learning process, namely: 1) Learning will attract more students' attention so that it can foster student learning motivation, 2) Learning materials are clearer in meaning so they can be better understood by students and enable it mastering and achieving learning objectives well, 3) teaching methods will be more varied, not merely verbal communication through the utterance of words by the teacher, and 4) students do more learning activities because they not only listen to teacher descriptions, but also other activities such as observing, doing, demonstrating, acting and others.

Based on the opinions above, it can be concluded that the functions and benefits of learning media are as materials, tools, and techniques used in teaching and learning activities, with the aim of stimulating students to be more enthusiastic in learning and can help students improve understanding, present data attractively and reliably, facilitating data interpretation and condensing information in order to achieve learning objectives.

\section{Powtoon animation}

Powtoon is a SaaS (Software as a Service)-based animation presentation media processing software which can be accessed through the www.powtoon.com site which can be used as a presentation tool for teachers in carrying out the learning process in the classroom. According to Ariyanto et al., (2018:123) Powtoon is an online application program that is on the internet and functions as a video maker application for presentations and learning media. Adhkar (2016:2) says that using Powtoon will make it easier for us to create animations for videos or presentations. The advantages of Powtoon itself are the interface in making videos that are good and easy to use and the availability of many funny and interesting animations that can be used to support the learning process. Powtoon is a free online service and its features are more complete and easier to create a presentation that has very interesting animation features including handwritten animation, animated cartoons, and livelier transition effects as well as timeline settings that are very easy and interesting so that students don't get bored.

\section{Powtoon animation benefits}

According to Maesyarah (2018:18) the benefits of Powtoon animation learning media, namely: 1) Powtoon media can clarify the presentation of messages so that they are not too verbalistic (in the form of written or spoken words), 2) Powtoon media can overcome the limitations of space, time and senses, such as: Objects that are too big, can be replaced with reality, films, frames, and pictures, 3) Media Powtoon can overcome motion that is too slow or too fast, 
can be assisted by timelapse or high-speed photography, and 4) Powtoon media can overcome the use of appropriate and varied educational media that can overcome the passive nature of children such as: enthusiasm for learning, allowing more direct interaction between students and the environment and reality, allowing students to learn independently according to their abilities and interests.

\section{Pros and cons powtoon animation}

According to Aprilianti (2019:10), the advantages of Powtoon animation media in learning are: (a) Its use is practical, easy to access with the www.powtoon.com website without having to download an application; (b) There are many choices of background templates so that in the worksheet you only need to insert images, text, audio and video that you want to use as teaching materials; (c) Animation content, fonts, and transition effects are available; (d) An attractive, dynamic and interactive display; (e) Can be saved in MPEG, MP4, AVI format, or directly shared on YouTube; and (f) In the form of learning videos that can combine video and audio images. Besides having advantages, Powtoon also has disadvantages, namely: (a) It is an online software that requires internet to open it; (b) To save requires internet with a stable speed because the end result is in the form of a video that has a large memory capacity; (c) Unpaid Powtoon users can only export files to those that require internet to open them.

\section{Powtoon media in learning}

The use of Powtoon in learning is relatively new and not many people know this Powtoon media. In the application of Powtoon media, it is not much different from Power Point media for presenting teaching materials, but Powtoon is more interesting because there are many choices of animated cartoons and can make the classroom atmosphere more lively and not boring.

Several previous studies, such as (Kafah et al., 2020; Choirudin et al., 2020; Susanti et al., 2020) found that the use of Powtoon-based learning video media had a positive effect in increasing students' interest in learning in the classroom. In addition, research (Rachmadina \& Pratiwi, 2021; Herawati et al., 2019) confirms that animation media in learning is very necessary in order to show mathematical concepts easily to students. Powtoon animation-based learning provides cognitive benefits to students in understanding each material. On the other hand, according to Buchori \& Cintang (2018) that Powtoon can affect students' concentration to focus on understanding existing animations so that the lesson content is easy to understand.

\section{Mathematical concept understanding ability}

Concept understanding according to Sumaryati (2017:8) is the ability of students to translate, interpret, conclude and also classify mathematical concepts in problem solving. The ability to understand can also be referred to as "understanding". Meanwhile, according to Pratiwi (2017:11) understanding mathematical concepts is mastering by receiving and understanding information obtained from learning seen through the ability to behave, think and act shown by students in understanding the definition, understanding, special characteristics, nature and core/content. of mathematical material and the ability to choose and use procedures efficiently and precisely. Furthermore, according to Nurhairunnisah (2017:20) a student is said to understand if the student is able to define, identify, describe, calculate and be able to conclude difficult material forms in their own sentences. Students who have a good level of understanding will be able to explain mathematical concepts according to what they understand.

Based on the some of the opinions above, it can be concluded that students' understanding of mathematical concepts is the ability to receive and understand information obtained by students from the lessons learned and capture meaning, namely translation, interpretation, and extrapolation of a basic idea about a mathematical object to solve mathematical problems using procedures systematically. efficient and precise.

\section{Indicators of understanding mathematical concepts}

Understanding mathematical concepts has indicators that can be used as a foothold by teachers in developing learning materials. According to Permendikbud (Minister of Education Regulation) number 58 of 2014, indicators of concept understanding are: 1) Restate the concepts that have been studied; 2) Classify objects based on whether or not the requirements are met to form the concept; 3 ) Identify the properties of operations or concepts; 4) Apply the concept logically; 5) Provide examples or counter examples; 6) Presenting concepts in various forms of mathematical presentation (tables, graphs, diagrams, drawings, sketches, mathematical models, or other means); 7) Linking various concepts in mathematics and outside mathematics; and 8) Developing the necessary and or sufficient conditions for a concept.

Zuliana (2017:2) states that a person is said to be able to understand mathematical concepts according to the Ministry of National Education if: 1) Able to restate a concept; 2) Able to classify an object according to certain properties according to the concept; 3) Able to give examples and non-examples of a concept; 4) Able to present concepts in various forms of mathematical representation and able to develop the necessary requirements of a concept; 5) Able to use, utilize, and choose certain procedures or operations; and 6) Able to apply concepts to problem solving.

Based on the indicators above, the indicators used by researchers for the continuation of their research are as follows: 1) Restate a concept; 2) Presenting concepts in the 
form of mathematical representations; and 3) Able to use, utilize, and choose certain procedures or operations.

\section{Scientific learning approach}

The school that will be conducting research is already using the 2013 curriculum learning. The 2013 curriculum is a student-centered curriculum that requires students to be active with a Scientific Approach. In this approach, students are required to think scientifically, namely observing, asking (interviewing), reasoning, and communicating what students have learned or what students know after following the lesson. According to Daryanto (2014:51) the scientific approach is an approach that uses scientific steps and rules in the learning process. The scientific steps applied include finding problems, formulating problems, proposing hypotheses, collecting data, analyzing data, and drawing conclusions. According to Musfiqon and Nurdyansyah (2015:57) the application of a scientific (scientific) approach in learning at school aims to familiarize students with thinking, acting, and working using scientific rules and steps. The learning process becomes more important than the learning outcomes.

Important components in teaching using a scientific approach can be translated into five learning practices (Musfiqon \& Nurdyansyah, 2015:38-40), namely: 1) Observing; 2) Asking; 3) Information Gathering; 4) Associating; and 5) Communication.

\section{Relevant research}

The results of Jatiningtias' research (2017) concluded that by using Powtoon learning media there was a significant difference in the use of learning media development with the Powtoon program in learning outcomes. while other research results, Maesyarah (2017) concluded that the resulting Powtoon product was categorized as very feasible based on validation from material experts with a percentage of $83 \%$ and media experts with a percentage of $82 \%$. Powtoon is very interesting to be used as teaching material based on the teacher's assessment that it gets a percentage of $81 \%$, and student responses in the small group trial get a percentage of $83 \%$ and the field trial gets a percentage of $81 \%$.

Research results of Awalia et al. (2019) it is concluded that the Powtoon animation learning media using the 4-D model has been developed based on the results of criticism and suggestions from experts so that it can be tested in class IV SDN Karangtumaritis. The results of the Aprilianti research (2019) concluded that the mathematics learning media using Powtoon with Trigonometry material with a contextual approach developed had met the valid/feasible criteria for use for class X SMK students. The results of Aryanto et al's research (2018) concluded that the use of Powtoon media can increase student interest and learning outcomes in basic competencies in describing economic actors in the Indonesian economic system for class VIIID SMP Nurul Islam Jember in the even semester of the 2017/2018 academic year.

The difference between this research and the relevant research above is that this research uses the ADDIE development model to develop Powtoon animation learning media which contains material on the flat side of the cube and the main beam surface area. The subjects used were media experts, material experts, small group trials, and large group trials (one experimental class). This research was also conducted to see the improvement of students' understanding of mathematical concepts in class VIII at MTsS Syamsuddhuha, North Aceh by developing Powtoon animation learning media.

\section{METHOD}

This type of study is Research and Development (R\&D) which produces a product in the form of Powtoon animation learning media. According to Sugiyono (2018: 297) research and development methods or in English Research and Development are research methods used to produce certain products and test the effectiveness of these products. This study aims to develop learning media in the form of animated Powtoon on the material of Constructing Flat Sides of Cubes and Blocks on the subject of surface area in improving the understanding of mathematical concepts for students of MTs class VIII and knowing the effectiveness of the learning media developed.

This study was used at Jalan Medan - Banda Aceh KM. 255 Cot Murong, Dewantara District, North Aceh Regency. The time of the research was carried out in the even semester of the 2020-2021 academic year. The study procedure uses the development model developed by Reiser and Mollenda in the 1990s, namely the ADDIE development model which consists of five stages which include analysis, design, development, implementation, and evaluation. (Evaluation) (Sugiyono, 2015:200). The reason the researcher uses the ADDIE model is that it has work procedures that refer to the Research and Development (R\&D) stage but are more systematic and simple so that they are able to produce more effective products (Rochimah, 2019:39).

The subject of this research consisted of the subject of the trial and the subject of the application of the product. The trial subjects were 2 media experts, 2 material experts, and 10 small group students who acted as subjects to assess the feasibility of the product. The subject of the application of the product is a large group of students, namely class VIII-2 MTs Swasta Syamsuddhuha, totaling 30 people who act as subjects to assess the effectiveness of using the product.

The types of data collected during the research process are qualitative and quantitative data. Qualitative data obtained are data in the form of descriptions of comments 
and suggestions from validators who are described and then general conclusions are made. The data was obtained to revise the developed product. The results of the expert validation analysis are input, feedback, criticism, and suggestions that are used as a reference in improving the learning media developed. While the quantitative data are in the form of scores from the assessment results of learning media by validators and scores from the test results of students' mathematical concept understanding abilities.

Data collection techniques in this study, namely: (1) Powtoon animation media assessment sheet, which consists of a validation questionnaire of media experts, material experts, and small group students; (2) a test of students' ability to understand mathematical concepts, conducted by giving test questions in the form of descriptions that have been tested beforehand with validity, reliability, discriminating power, and difficulty index tests, the test items consist of pretest and posttest; (3) interview, which aims to find out about the learning process after using Powtoon animation learning media.

\section{Quantitative data analysis}

(1) Data Analysis of Expert Assessment Questionnaire Results and Student Assessment

Expert assessment using a Likert scale of $1-5$ is presented in the table below:

Table 1. Rules for Scoring Assessment

\begin{tabular}{cc}
\hline Category & Score \\
\hline Very Good & 5 \\
\hline Good & 4 \\
\hline Pretty Good & 3 \\
\hline Deficient & 2 \\
\hline Not Good & 1 \\
\hline
\end{tabular}

Source: Sugiyono (2013:93)

The total assessment score obtained, we enter into the Likert scale category level with the formula (Sugiyono, 2013:95):

$P_{k}=S / N \times 100 \%$.

Information:

$$
\begin{array}{ll}
P_{k} & : \text { Eligibility scale category value } \\
S & : \text { Total score obtained } \\
N & : \text { Total score ideal }
\end{array}
$$

The value of the feasibility scale category is as follows:

Table 2. Feasibility Scale of Powtoon Animation Media Products

\begin{tabular}{cc}
\hline Eligibility Scale & Criteria \\
\hline $81 \%-100 \%$ & Very Feasible \\
\hline $61 \%-80 \%$ & Feasible \\
\hline $41 \%-60 \%$ & Decent Enough \\
\hline $21 \%-40 \%$ & Less Feasible \\
\hline $0 \%-20 \%$ & Very Unfeasible
\end{tabular}

Source: (Maesyarah, 2018:48)

\section{(2) Pretest and Posttest Data Analysis}

The analysis of the results of the pretest and posttest was carried out by giving a concept understanding test question and measuring the learning outcomes to see the level of effectiveness of the product determined based on the average gain. The gain score (g) obtained is the result of a comparison between the average pretest and posttest scores. The increase in student learning outcomes obtained before and after using Powtoon animation learning media, is calculated using the $\mathrm{N}$-Gain formula. With the Hake formula (in Nurhairunnisah, 2016:83):

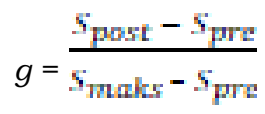

Information:

g : normalized gain score

$S_{\text {vre }}:$ : Average pretest score

$s_{\text {vost }}:$ Average posttest score

$s_{\text {mahs }}$ : maximum score

With the criteria for the acquisition rate of the $\mathrm{N}$-Gain index as follows:

Table 3. N-Gain index acquisition rate criteria

\begin{tabular}{cc}
\hline $\mathrm{N}$-Gain Index & Criteria \\
\hline $0,70 \leq \mathrm{g} \leq 1,00$ & High \\
\hline $0,30 \leq \mathrm{g}<0,70$ & Currently \\
\hline $0,00<\mathrm{g}<0,30$ & Low \\
\hline $\mathrm{g}=0,00$ & No increase \\
\hline$-1,00 \leq \mathrm{g}<0,00$ & There is a decrease \\
\hline
\end{tabular}

Source: Nismalasari et al (2016:83)

\section{Qualitative data analysis}

Qualitative data were obtained from input or responses from experts, small group students, and the results of interviews. These data were analyzed descriptively qualitatively (Kusniawati, 2015:63). Feedback or input from experts and small group students that are constructive and considered appropriate for the development of learning media are used as improvement materials at the revision stage of the Powtoon animation media product.

\section{RESULTS AND DISCUSSION}

\section{Results}

The results of the development of Powtoon animation learning media using the ADDIE development model are in the form of learning videos. The making of this learning video using Powtoon lasted for 1 week. The making of Powtoon animation media is based on the Powtoon animation script in the form of a storyboard that has been designed at the Design stage. The results of making the opening Powtoon animation video (see Figure 3). 


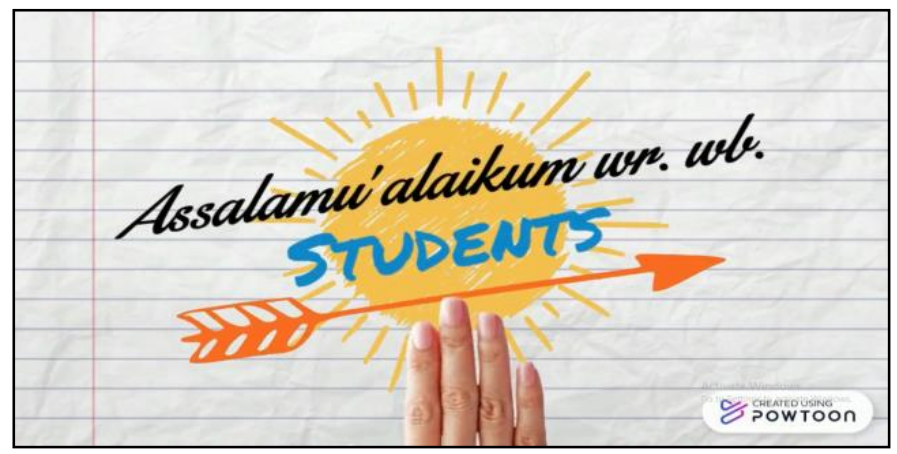

Figure 3. Powtoon Animation Opening Video Results

The Powtoon animated learning videos that have been developed are validated by media experts, material experts, and small group students. The results of validation from the validators (see Table 4).

\section{Media expert}

Media experts play a role in validating media in terms of media quality, media use, and media layout carried out by 2 lecturers of Mathematics Education, Malikussaleh University.

Table 4. Media Expert Validation Results

\begin{tabular}{cccc}
\hline \multirow{2}{*}{ Validator } & \multicolumn{3}{c}{ Assessment Aspect } \\
\cline { 2 - 4 } & Media Quality & Media Usage & $\begin{array}{c}\text { Media } \\
\text { Layouts }\end{array}$ \\
\hline Media Expert I & 53 & 19 & 25 \\
\hline Media Expert II & 50 & 19 & 24 \\
\hline Total & 103 & 38 & 49 \\
\hline Percentage & $94 \%$ & $95 \%$ & $98 \%$ \\
\hline Average (\%) & \multicolumn{3}{c}{$96 \%$} \\
\hline Category & Very Feasible \\
\hline
\end{tabular}

\section{Material expert}

Material experts play a role in validating the media in terms of material, language, and implementation carried out by 2 mathematics teachers at MTsS Syamsuddhuha.

Table 5. Material Expert Validation Results

\begin{tabular}{cccc}
\hline \multirow{2}{*}{ Validator } & \multicolumn{3}{c}{ Assessment Aspect } \\
\cline { 2 - 4 } & Material & Language & Execution \\
\hline Material Expert I & 50 & 18 & 13 \\
\hline Material Expert II & 53 & 19 & 14 \\
\hline Total & 103 & 37 & 27 \\
\hline Percentage & $94 \%$ & $93 \%$ & $90 \%$ \\
\hline Average (\%) & \multicolumn{4}{|}{ Very Feasible } \\
\hline Category &
\end{tabular}

\section{Small group students}

Small group students play a role in assessing the media in terms of learning, appearance, and convenience carried out by 10 students who have studied the material for building flat sides on the subject of surface area of cubes and blocks.
Table 6. Small Group Student Validation Results

\begin{tabular}{cccc}
\hline \multirow{2}{*}{ Validator } & \multicolumn{3}{c}{ Assessment Aspect } \\
\cline { 2 - 4 } & Media Quality & Media Usage & Media Layouts \\
\hline S1 & 28 & 37 & 28 \\
\hline S2 & 29 & 36 & 29 \\
\hline S3 & 26 & 35 & 28 \\
\hline S4 & 29 & 37 & 27 \\
\hline S5 & 29 & 38 & 30 \\
\hline S6 & 28 & 36 & 29 \\
\hline S7 & 28 & 35 & 27 \\
\hline S8 & 26 & 37 & 28 \\
\hline S9 & 29 & 38 & 30 \\
\hline S10 & 30 & 38 \\
\hline Total & 282 & 367 & 285 \\
\hline Percentage & $94 \%$ & $92 \%$ \\
\hline Average $(\%)$ & \multicolumn{4}{c}{$94 \%$} \\
\hline Category & \multicolumn{3}{|}{ Very Feasible } \\
\hline
\end{tabular}

\section{Powtoon animation media product revision}

After the product validation stage is carried out, then the Powtoon animation media is corrected according to the suggestions and comments from the validators. The validators concluded that the learning media was good and feasible to use after revisions according to suggestions. There are several comments and suggestions given by the validators, including: 1) white writing needs to be corrected; 2) only one animated character is used; 3) lack of block images to clarify the material; 4) there is an error in the placement of colors on the beam nets; and 5) the sound of the accompaniment material is too flat.

Based on the comments and suggestions of the validators, the Powtoon animation media needs to be revised even though it is feasible to use it to improve the developed learning media. The revisions that have been made to the development of Powtoon animation media are: 1) changing the color of the white text to black to make it clearer; 2) only one animated character is used to represent a teacher; 3) adding a picture of the shape of a block with its description on the discovery slide of the formula for the surface area of a block; 4) correcting the color placement error on the beam nets; and 5) the accompaniment of the material is improved by setting the intonation high or low when recording the sound. The research data obtained were then analyzed to determine the feasibility and effectiveness of using Powtoon Animation learning media.

\section{Data analysis of the feasibility powtoon animation products}

The data on the feasibility of the Powtoon animation media product was obtained from the results of product validation by the validators at the development stage (Development). The results of product validation by media experts, material experts, and small group students, and table of feasibility results (see Table 7). 
Table 7. Powtoon Animation Media Product Feasibility Results

\begin{tabular}{ccc}
\hline Validator & Average (\%) & Category \\
\hline Media Expert & $96 \%$ & Very Feasible \\
\hline Material Expert & $92 \%$ & Very Feasible \\
\hline Small Group Students & $94 \%$ & Very Feasible \\
\hline Total Percentage & $282 \%$ & \multirow{2}{*}{ Very Feasible } \\
\hline Average (\%) & $94 \%$ & \\
\hline
\end{tabular}

Based on table 7 above, the results of the feasibility of Powtoon animation media products are also presented in the following diagram:

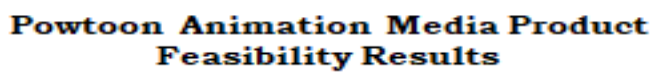

Product E 1igibility Results

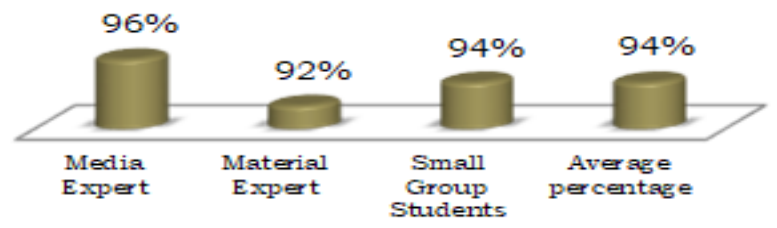

Figure 4. Powtoon Animation Media Feasibility Result Diagram

Based on Table 7 and Figure 4 above, it shows that the results of the feasibility of Powtoon animation media products from each validator are 96\% media experts, 92\% material experts, and 94\% small group students with an average percentage of $94 \%$ included in the category " Very Feasible". Thus, it can be concluded that the Powtoon animation media product is feasible to be used in the learning process as a tool for students to understand the material for building flat sides on the subject of surface area of cubes and blocks.

\section{Data Analysis of the effectiveness of using powtoon animation products}

Product effectiveness data was obtained at the implementation stage by giving pretest and posttest. Giving pretest and posttest aims to determine the level of effectiveness of Powtoon animation learning media products developed in improving students' understanding of mathematical concepts by looking at the difference in scores before and after using Powtoon animation media products. Based on the results of the students' pretest and posttest, it was found that the average pretest score was 43,44 and the posttest average score was 84,27 which showed an increase. The difference in the average pretest and posttest scores for each item is presented in the Figure 5.

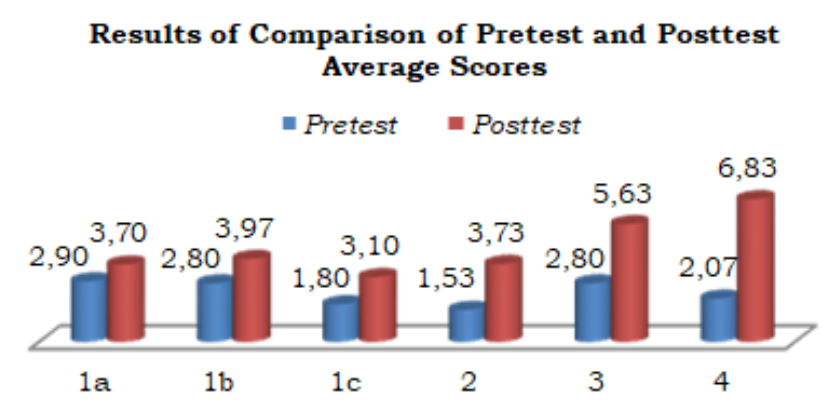

Figure 5. Diagram of the Average Pretest and Posttest Score

Besides being seen from the average pretest and posttest obtained, it is also seen from the N-Gain calculation. Based on the calculation of $\mathrm{N}$-Gain obtained from the comparison of pretest and posttest values in learning using Powtoon animation media is 0.72 with the "High" category (N-Gain 0.7 ) so that there is an increase. The increase in the posttest average value and the $\mathrm{N}$-Gain calculation shows that Powtoon animation learning media is effective in improving understanding of mathematical concepts after students use Powtoon animation media products in learning.

\section{Data analysis of interview results using powtoon animation products}

Based on the analysis of the results of interviews from 10 representatives of large groups of students, it can be concluded that Powtoon animation learning media can make students interested in learning because it is equipped with animation features and questions from videos that can sharpen students' minds so that students are enthusiastic and active during the learning process. take place. In addition, Powtoon animation learning media can also visualize abstract mathematical material so that students can easily understand the material presented.

\section{Discussion}

Based on the results of the development, it can be seen that the product that has been successfully developed in this research and development (R\&D) is the Powtoon animation learning media product. The final product is a learning video in .MP4 format with a duration of 6 minutes 53 seconds. This learning video is also available on YouTube with the link https://youtu.be/GjIvthsqZJY. This learning media explains the subject of the surface area of cubes and blocks, namely the introduction of cubes and blocks, examples of cube-shaped objects and blocks, cube and block formulas, sample questions, and available practice questions. This Powtoon animation product serves as a tool to support students' ability to understand and clarify the concept of surface area of cubes and blocks from the material being studied. 
This is in line with the notion of learning media according to Kustandi (2011: 9) which is a tool that can help the teaching and learning process and serves to clarify the meaning conveyed so that it can achieve good and perfect learning objectives.

Powtoon animation learning media that is ready to be developed will be tested for the feasibility and effectiveness of using the product in improving students' understanding of mathematical concepts. Based on the analysis of the product validation results by the two media experts, an average value of 4,8 was obtained with a percentage of $96 \%$ which was classified as very feasible. The results of product validation by the two material experts obtained an average value of 4,6 with a percentage of $92 \%$ which was classified as very feasible. Furthermore, the results of product validation by ten small group students obtained an average value of 4,7 with a percentage of $94 \%$ which is also classified as very feasible. From the results of the average value and percentage obtained, it shows that the Powtoon animation learning media product developed is very feasible and can be used in the learning process in Class VIII MTsS Syamsuddhuha.

The product validation sheet also provides a place for comments or suggestions or opinions from the validators. The validators gave an opinion that overall the videos developed were good, educative, easy to understand and had met the standards with some suggestions for improvement. From this opinion, it can be concluded that the Powtoon animation learning video is suitable for use in the learning process because it can present abstract learning materials in audio-visual form so that students more easily understand the concepts of the material.

In testing the effectiveness of Powtoon animation learning media products on the subject of the surface area of cubes and blocks, this is done in two ways, namely through an understanding test before using Powtoon animation media through Pretest. And after using Powtoon animation media, the subject of the surface area of cubes and blocks through the Posttest at MTsS Syamsuddhuha with a total of 30 students. Based on the results of the pretest average of 43,44 and the average posttest value of 84,27 with the acquisition of an N-Gain value of 0,72 with the high category showing an increase. From the average value of pretest and posttest and the obtained N-Gain value, it shows that there is an increase in concept understanding after applying the learning process with Powtoon animation learning media products so that the product is effectively used in the learning process at MTsS Syamsuddhuha school. The Powtoon animation learning media product is considered effective in improving concept understanding because the material presented is not only in the form of text and images, but also includes animations and audio that can visualize and clarify the content of the material. This is supported by the opinion of Rogness
(2011) which states that the use of visualization can help students in increasing understanding of concepts. This statement is also supported by research conducted by Awalia et al., (2019) that learning media in the form of Powtoon animation can help students understand concepts.

Information about the use of the product is also known from the results of interviews conducted with 10 students after learning by using the Powtoon animation learning media product. Interviews were conducted so that researchers get information directly from students about the developed media products. Based on the results of interviews, it can be concluded that the Powtoon animation learning media product can make students easy to understand the material presented. This media also provides interest through the animations in it so that it makes students enthusiastic and active during the learning process. Because students understand the concept of learning, students also understand how to answer practice questions properly and correctly. This Powtoon animation learning media product is a learning product that is being implemented for the first time at the school.

\section{CONCLUSION}

Based on the results of research and development, it can be concluded that: (1) The Powtoon animation learning media on the flat-sided building material on the subject of the surface area of cubes and blocks developed already meets the valid/feasible criteria for use in class VIII MTsS Syamsuddhuha. The feasibility of the development product can be seen from the results of the validator's assessment which states that it is very feasible. The results of the assessment of media experts obtained a percentage value of $96 \%$, the results of the assessment of material experts obtained a percentage value of $92 \%$, and the results of the assessment of small group students obtained a percentage value of $94 \%$. (2) The use of Powtoon animation learning media that was developed was considered effective in increasing students' understanding of mathematical concepts seen from the average pretest score of 43,44 an increase in the posttest of 84,27 with an $\mathrm{N}$-Gain value of 0,72 . So the use of Powtoon animation learning media products is effective in increasing the understanding of mathematical concepts for class VIII students of MTsS Syamsuddhuha.

\section{RECOMMENDATIONS}

The results of research and development of Powtoon animation learning media in mathematics learning the subject matter of surface area of cubes and blocks for class VIII are recommended some suggestions from researchers as follows:

To Teacher

a. The development of Powtoon animation learning media, the subject matter of the surface area of cubes 
and blocks for class VIII, can be used in the learning process.

b. Teachers can develop learning videos with Powtoon on undeveloped math subject matter.

c. To the Next Researchers.

d. It is hoped that it can develop Powtoon animation learning media with mathematical material that has not been developed and use more interesting animations.

e. It is hoped that further researchers who develop Powtoon media in learning mathematics should vary the learning process by applying cooperative learning models so that the learning process is more interesting and more exciting.

\section{Acknowledgements}

The authors would like to thank all parties who have assisted in the research and writing of this manuscript so that it deserves to be widely published to the academic community.

\section{REFERENCES}

Adhkar, B.I. (2016). Pengembangan Media Video Animasi Pembelajaran Berbasis Powtoon pada Kelas 2 Mata Pelajaran Ilmu Pengetahuan Alam di SD Labschool Unnes (Skripsi). UNS, Semarang.

Aprilianti, P. (2019). Pengembangan Media Pembelajaran dengan Menggunakan Powtoon pada Materi Trigonometri Siswa SMK PAB Helvetia T.P 2019/2020 (Skripsi). UMSU, Sumatera Utara.

Ariyanto, R., Kantun, S., \& Sudikin. (2018). "Penggunaan Media Powtoon untuk Meningkatkan Minat dan Hasil Belajar Siswa pada Kompetensi Dasar Mendeskripsikan PelakuPelaku Ekonomi dalam Sistem Perekonomian Indonesia". Jurnal Pendidikan Ekonomi, 12(1), 122-127. DOI: https://doi.org/10.19184/jpe.v12i1.7622

Arsyad, A. (2013). Media Pembelajaran. Jakarta: Rajagrafindo Persada.

Awalia, I., Pamungkas, A. S., \& Alamsyah, T. P. (2019). Pengembangan Media Pembelajaran Animasi PowToon pada Mata Pelajaran Matematika di Kelas IV SD. Jurnal Matematika Kreatif-Inovatif (Kreano), 10(1), 49-56. DOI: https://doi.org/10.15294/kreano.v10i1.18534

Barbara, N. K. R., Bayu, G. W., \& Agustiana, I. G. A. T. (2021). Powtoon-Based Animated Videos as Learning Media for Science Content for Grade IV Elementary School. International Journal of Elementary Education, 5(4). DOI: http://dx.doi.org/10.23887/ijee.v5i4.39821

Buchori, A., \& Cintang, N. (2018). The Influence of PowtoonAssisted Group to Group Exchange and Powtoon-Assisted Talking Chips Learning Models in Primary Schools. International journal of Evaluation and Research in Education, 7(3), 221-228. https://eric.ed.gov/?id=EJ1198645

Choirudin, C., Ningsih, E. F., Amrulloh, H., Anwar, M. S., Azizah, I. N., \& Prastika, M. S. (2020). Development of Learning Media for Ethnomathematics and Culture of Lampung with the
Powtoon Application. Jurnal Tadris Matematika, 3(2), 141152. DOI: https://doi.org/10.21274/jtm.2020.3.2.141-152

Daryanto. (2014). Pendekatan Pembelajaran Saintifik Kurikulum 2013. Yogyakarta: Gava Media.

Departemen Pendidikan Nasional Indonesia. (2014). Kamus Besar Bahasa Indonesia. Jakarta: Pusat Bahasa.

Herawati, R., Sulisworo, D., \& Fayanto, S. (2019). The development of learning videos on powtoon-based work and energy topics to support flipped classroom learning. IOSR J. Res. Method Educ, 9(4), 51-58. DOI: https://doi.org/10.9790/1959-0904015158

Jatiningtias, N. H. (2017). Pengembangan Media Pembelajaran Powtoon untuk Meningkatkan Hasil Belajar Siswa Mata Pelajaran IPS Materi Penyimpangan Sosial di SMP Negeri 15 Semarang (Skripsi). UNS, Semarang.

Kafah, A. K. N., Nulhakim, L., \& Pamungkas, A. S. (2020). Development of video learning media based on powtoon application on the concept of the properties of light for elementary school students. Gravity: Jurnal Ilmiah Penelitian dan Pembelajaran Fisika, 6(1). DOI: DOI: http://dx.doi.org/10.30870/gravity.v6i1.6825

Kartika, Y. (2018). Analisis Kemampuan Pemahaman Konsep Matematis Peserta Didik Kelas VII SMP pada Materi Bentuk Aljabar. Jurnal Pendidikan Tambusai, 2(4), 777-785. DOI: https://doi.org/10.31004/jptam.v2i4.25

Kementerian Pendidikan dan Kebudayaan Republik Indonesia. (2014) "Peraturan Menteri Pendidikan dan Kebudayaan Nomor 58 Tahun 2014 Tentang Kurikulum Sekolah Menengah Pertama/Madrasah Tsanawiyah". Jakarta: Kementerian Pendidikan dan Kebudayaan Republik Indonesia.

Kusniawati, A. (2015). Pengembangan Bahan Ajar dengan Pendekatan Kontesktual pada Materi Kubus dan Balok untuk Meningkatkan Kemampuan Koneksi Matematis dan Pemecahan Masalah Siswa Kelas VIII SMP ISS Jatipurno Wonogiri (Tesis). UNY, Yogyakarta.

Kustandi, C., \& Sutjipto, B. (2011). Media Pembelajaran: Manual dan Digital. Bogor: Ghalia Indonesia.

Latifah, N., \& Lazulfa. (2020). Desain dan Uji Coba Media Pembelajaran Berbasis Video Animasi Powtoon sebagai Sumber Belajar pada Materi Sistem Periodik Unsur. Journal Education and Chemistry, 2(1), 26-31.

https://ejournal.uniks.ac.id/index.php/JEDCHEM/article/view/4 28

Maesyarah, I. A. (2018). Pengembangan Media Pembelajaran Fisika Berbasis Powtoon pada Materi Dinamika untuk SMA Kelas X (Skripsi). UIN Raden Intan Lampung, Bandar Lampung.

Mulyaningtias, L. K. (2016). Pengembangan Media Pembelajaran Berbasis Adobe Flash CS3 pada Pelajaran Matematika di Kelas VIII C MTs Negeri Tulungagung Tahun Ajaran 2015/2016 (Skripsi). IAIN Tulungagung, Tulungagung.

Musfiqon, HM. \& Nurdyansyah. (2015). Pendekatan Pembelajaran Saintifik. Sidoarjo: Nizamia Learning Center.

Nismalasari, Santiani, \& Rohmadi, H. M. (2016). "Penerapan Model Pembelajaran Learning Cycle terhadap Keterampilan 
Proses Sains dan Hasil Belajar Siswa pada Pokok Bahasan Getaran Harmonis". Jurnal EduSains, 4(4), 74-94. DOI: https://doi.org/10.23971/eds.v4i2.511

Nurhairunnisah. (2017). Pengembangan Bahan Ajar Interaktif untuk Meningkatkan Pemahaman Konsep Matematika pada Siswa Kelas X (Tesis). UNY, Yogyakarta.

Pratiwi, R. S. (2017). Pengaruh Metode Problem Posing terhadap Pemahaman Konsep Matematis Siswa (Skripsi). Universitas Lampung, Bandar Lampung.

Rachmadina, D., \& Pratiwi, D. D. (2021, February). Developing mathematics video assisted by powtoon application in contextual learning approach. In Journal of Physics: Conference Series (Vol. 1796, No. 1, p. 012027). IOP Publishing. URL:

https://iopscience.iop.org/article/10.1088/17426596/1796/1/012027/meta

Ramli, M. (2012). Media dan Teknologi Pembelajaran. Banjarmasin: IAIN Antasari Press.

Rogness, J. (2011). "Mathematical Visualitation". Journal of Mathematics Education at Teachers College. Fal-Winter 2011, 2, 1-7.
Sudjana, N., \& Rivai, A. (2011). Media Pembelajaran. Bandung: Sinar Baru.

Sugiyono. (2013). Metode Penelitian Kuantitatif, Kualitatif, dan $R \& D$. Bandung: Alfabeta.

Sugiyono. (2015). Metode Penelitian Kuantitatif, Kualitatif, dan $R \& D$. Bandung: Alfabeta.

Sugiyono. (2018). Metode Penelitian Kuantitatif, Kualitatif, dan $R \& D$. Bandung: Alfabeta.

Sukiman. (2012). Pengembangan Media Pembelajaran. Yogyakarta: Pedagogia.

Sumaryati, S. (2017). Peningkatan Pemahaman Konsep Matematis Siswa melalui Penerapan Model Pembelajaran Kooperatif Tipe TPS (Skripsi). Universitas Lampung, Bandar Lampung.

Susanti, V. D., Andari, T., \& Harenza, A. (2020). Web-Based Learning Media Assisted By Powtoon in Basic Mathematics Course. Al-Jabar: Jurnal Pendidikan Matematika, 11(1), 1120. DOI: https://doi.org/10.24042/ajpm.v11i1.5308

Zuliana, E. (2017). "Penerapan Inquiry Based Learning Berbantuan Peraga Manipulatif dalam Meningkatkan Pemahaman Konsep Matematika pada Materi Geometri Mahasiswa PGSD Universitas Muria Kudus". Jurnal Pendidikan, 8(1), 35-47. 